\title{
„SPES CONFISA Deo”
}

\section{OSOBY:}
ANNA
CHIMEK
TADEUSZ
ELŻBIETA
ZACHARY
BIZNESMAN
STARUSZKA
PIELĘGNIARKA
RITA

\section{SCENA I}

W oddali stychać odgłosy miasta (szum samochodów, gwar, uliczny zgiełk). Na scene wchodza nerwowo aktorzy - ktoś wbiega, ktoś wchodzi powoli, parę osób mija się, potraca, rozmawiajac przez telefon. W rogu, w pozycji pótleżącej znajduje się TADEUSZ - bezdomny człowiek $w$ łachmanach, po przeciwległej stronie na ławeczce siedzi starsza, skromnie ubrana pani. Nieopodal przechadza sie młoda dziewczyna zdecydowanie wypatrujaca kogoś. Nagle pełne światła gasna, postaci zastygaja w bezruchu, a na czarnym ekranie $w$ tle pojawia się jasny napis „Zatrzymaj się, to przemijanie ma sens” - Jan Paweł II. Chwilę później na postaci padaja pojedyncze snopy światła. Następnie wszystko gaśnie, światło pada tylko na jedna osobę-Anne, pozostałe wychodza.

\section{ANIA}

(do siebie)

Gdzie on jest?! Znów się spóźnia! A może nie przyjdzie, w końcu to nasze piąte spotkanie, nikt nie mówił nic o żadnym związku. Może gdybym wtedy...

\section{CHIMEK}

Ania, cześć! Przepraszam za spóźnienie, autobus mi uciekł. 
ANIA

Mogłeś napisać, zadzwonić. Martwiłam się.

\section{CHIMEK}

Naprawdę?

\section{ANIA}

Nie, na żarty, wiesz co!

\section{CHIMEK}

Czyli ci zależy...

\section{ANIA}

Mi?! Nie! Wcale nie.

\section{CHIMEK}

(przekornie)

Jeśliby ci nie zależało, to byś się nie denerwowała.

\section{ANIA}

Przestań, ja tak tylko... Zresztą, nieważne! Po prostu nie lubię, jak ktoś wystawia mnie do wiatru.

\section{CHIMEK}

No już, już. Nie obrażaj się.

(wyciaga mały bukiecik kwiatków)

Masz, to dla ciebie!

\section{ANIA}

Jejku, przecież to fiołki! Moje ulubione! Skąd wiedziałeś?

\section{CHIMEK}

Właściwie to nie wiedziałem. Zwyczajnie miałem nadzieję, że ci się spodobają.

Światła gasną, na moment zapada cisza. Aktorzy wychodzą.

\section{SCENA II}

Na scenę wchodzi mężczyzna w łachmanach, pcha wózek ze złomem, głośno wzdycha. Widać zmęczenie, zniechęcenie. Staje na środku sceny, wyciaga pożótkła fotografię. 


\section{TADEUSZ}

Gdybyś tylko wiedział, przyjacielu, ile mnie ta twoja przyzwoitość kosztuje, to nigdy byś mnie nie potępiał...

Kiedy nie piję, jest mi źle. Rozumiesz?!

Jestem zupełnie sam, bez rodziny, bez domu, bez pracy, bez perspektyw. Jestem tylko ja i ten wózek. A miało być tak pięknie... Sen o potędze. Ameryka. Kraj miodem i mlekiem płynący. Wielkie pieniądze. Salony. Kobiety. I było... Przez chwilę, dopóki nie wpadłem w to bagno. Bo widzisz. Przyszły pieniądze, przyszło wystawne życie, przyszło kasyno, a potem przyszedł też komornik!

Wszyscy się odwrócili, no, może nie wszyscy, jej to sam kazałem sobie pójść. A i tak długo trwała przy mnie...

Ehh, teraz to nie ma większego znaczenia, znalazłem pocieszenie. (wyjmuje zza pazuchy butelkę) Jest złom, jest i potem butelka. (próbuje ja otworzyć) Dziś usłyszałem, że mogę jeszcze zmienić swoje życie... Że wciąż jestem coś wart, tamta pani... Jej historia... Ona jest jeszcze bardziej samotna, przygnębiona i smutna, a mimo to uśmiechnęła się do mnie i dała mi bułkę... (po policzku spływa mu łza, ręka zaczyna drżeć, butelka wypada mu z rąk, roztrzaskuje się. Mężczyzna zadziera wzrok, patrzy $w$ niebo)

Światła gasną, słychać tylko skrzypienie wózka, aktor wychodzi.

\section{SCENA III}

Na scenę wchodzi kobieta w średnim wieku, w pośpiechu zapina płaszcz, po chwili staje, odwraca się i głośno woła:

ELA

Zachary! Pośpiesz się, bo się spóźnimy!

\section{ZACHARY}

( $z$ oddali)

Już idę, idę.

ELA

Tylko nie zapomnij tej kartki z numerkiem do zapisu!

Do kobiety dobiega mężczyzna elegancko ubrany, z damskim beretem w ręku i parasolką.

\section{ZACHARY}

Już dawno włożyłem ją do teczki. Kochanie, ubierz się spokojnie i załóż czapkę, bo już dawno skończyła się złota polska jesień. Jeszcze mi się przeziębisz. 


\section{ELA}

Tak, tak, listopad za pasem. A my wciąż nic...

\section{ZACHARY}

No chodź, nie ma co gdybać.

Na drugim końcu sceny stoi biurko, za nim siedzi młody lekarz.

\section{DOKTOR}

Witam serdecznie, miło państwa widzieć. Wczoraj otrzymałem wyniki ostatnich badań. Może nie są rewelacyjne, ale...

\section{ZACHARY}

(przerywajac lekarzowi)

Przepraszam, czy możemy porozmawiać na osobności?

Elu, pozwolisz?

\section{ELA}

(wyraźnie zaskoczona)

Mam wyjść?

\section{ZACHARY}

Tak, bardzo Cię proszę.

ELA

Ale dlaczego?!

\section{ZACHARY}

Tylko na momencik, zaraz Cię poproszę do gabinetu z powrotem.

\section{ELA}

Nic z tego nie rozumiem... Ale dobrze, wyjdę.

Kobieta posłusznie wstaje i opuszcza gabinet. ZACHARY pochyla się w stronę lekarza.

\section{ZACHARY}

Panie...

(próbujac odczytać imię lekarza $z$ identyfikatora)

\section{DOKTOR}

(z uśmiechem na ustach, spokojnym tonem)

Gabrielu. 


\section{ZACHARY}

Tak, tak.

Panie Gabrielu, może nie jestem lekarzem, ale swoje wiem. Proszę powiedzieć mi prawdę. Ela wciąż pragnie dziecka, a staramy się o nie od lat. Zegar biologiczny tyka, skoro do tej pory się nie udało, to może trzeba przestać się łudzić i spojrzeć prawdzie w oczy. Proszę nie dawać jej fałszywych obietnic. Rozczarowanie boli najbardziej...

\section{DOKTOR}

Proszę Pana, jedyna prawda, jaką mam do przekazania, to taka, że pani Elżbieta ma jeszcze realne szanse na zajście w ciążę. Trzeba tylko w to uwierzyć, a z Pana nastawieniem będzie bardzo trudno.

\section{ZACHARY}

Ehh, jest pan taki uparty! Najchętniej zmieniłbym lekarza, ale żona, nie wiedzieć cze$\mathrm{mu}$, ma do pana pełne zaufanie. $\mathrm{W}$ takim razie ja już do tego nie będę ręki przykładał. I słowem się nie odezwę!

Światła gasną, aktorzy wychodza ze sceny.

\section{SCENA IV}

Na scenę wbiega młody mężczyzna w garniturze z neseserem i telefonem komórkowym w ręku. Krąży po scenie.

\section{BIZNESMAN}

Tak, tak. Sto dwadzieścia tysięcy. Euro? Nie ma problemu, oczywiście. Proszę wysłać dane do przelewu... Proszę chwileczkę poczekać, mam drugie połączenie na linii.

Tak, słucham?...

(wyraźnie zdenerwowany, podniesionym głosem)

Mamo! Ile razy mówiłem Ci, żebyś mi nie przeszkadzała w ciągu dnia! Nie, nie mam czasu dziś... Ciotka Hiacynta? Nie pamiętam takiej... Dobrze, jak znajdę czas to do niej pojadę! Wyślij mi adres mailem!... no tak, nie umiesz. Zadzwonię później, mam ważną rozmowę na linii.

\section{(uprzejmym tonem)}

Już jestem. Oczywiście, że mogę się z Panem spotkać na podpisanie umowy. Dziś po południu?

Mężczyzna zerka na zegarek, przyśpiesza, wybiega ze sceny. Światło pada na przeciwległa stronę. Na prostym, drewnianym krześle siedzi starsza pani. Ze smutna mina odkłada słuchawke czerwonego telefonu. Powoli wstaje, podchodzi do ramki ze zdjęciem dziecka. 


\section{STARUSZKA}

Kiedyś miałeś czas dla mnie, dla rodziny. Żyliśmy skromnie, ale niczego Ci nie brakowało. Skąd więc ten pęd za pieniędzmi? I od kiedy to nie pamiętasz ciotki, która pomagała mi się Tobą opiekować po śmierci Twojego taty...

\section{SCENA V}

$\mathrm{Na}$ środku sceny stoi szpitalne tóżko, na nim leży starsza kobieta, obok stoi zniszczone krzesło. Do sali wchodzi zmęczona PIELĘGNIARKA z kroplówką w ręku i pojemniczkiem leków.

RITA

(próbując się podnieść na przedramionach, delikatnym głosem)

Dzień dobry siostrzyczko!

\section{PIELEGNIARKA}

Dzień dobry pani Rito! Jak się pani dzisiaj czuje?

\section{RITA}

(próbując się uśmiechnać, pokonać grymas bólu)

Całkiem nieźle, kochana. Lepiej powiedz, jak tam u Ciebie? Jak przeprowadzka? Mieszkanie już gotowe?

\section{PIELĘGNIARKA}

Jeszcze nie. Andrzej nawet nie położył tapet w pokojach dziewczynek. No po prostu nie mam do niego już siły! Wciąż wymyśla jakieś problemy! A to wężyk się urwał pod zlewem, a to lakier odprysnął, a to tynk odpadł. Ten dom w jego oczach to istna ruina! Dla mnie to on szuka ciągłych wymówek!

\section{RITA}

Musisz być bardziej cierpliwa, moja siostra mawiała zawsze, że „co nagle, to po diable”.

\section{PIELĘGNIARKA}

Ależ skąd! Robić mu się nie chce i tyle! Gdyby tylko pani wiedziała, ile ja mam zmartwień na głowie. Dziewczynki idą w tym roku do szkoły, trzeba kupić podręczniki, mundurki, plecaki. Do tego jeszcze wycieczki, wyjścia z klasą do kina czy gdzieś. A skąd na to wziąć pieniądze?! Ja robię na dwa etaty, haruję dzień i w noc, a on nic!

\section{RITA}

Kochana, myślę, że twój mąż potrzebuje jeszcze trochę czasu. Niedawno stracił pracę, załamał się. Tyle lat w tej samej firmie, a świat pędzi, i teraz trudno mu się odnaleźć na rynku... (atak kaszlu) 


\section{PIELEGNIARKA}

Ojej, pani Rito. Proszę się nie nadwyrężać. Dziś powinien przyjść lekarz, może przepisze coś silniejszego? Przecież inni pacjenci proszą o leki przeciwbólowe, skarżą się, krzyczą. A pani tak spokojnie znosi to wszystko...

\section{RITA}

To dla mnie lekcja pokory i wiary, kochana.

\section{PIELĘGNIARKA}

Czy ja mogę coś dla Pani zrobić?

RITA

Właściwie to tak. Pójdź na mszę i pomódl się.

\section{PIELEGGIARKA}

O pani uzdrowienie?

\section{RITA}

Nie, nie o uzdrowienie. (znów próbując się uśmiechnąć)

Pomódl się za męża, za siebie samą, za wasze małżeństwo.

Światła gasną. Aktorzy wychodza.

\section{SCENA VI}

W tle znów uliczny gwar, tym razem zgaszone światła, aktorzy na scenie. Odgłosy miasta wyciszaja się. Powoli na scenę padaja pojedyncze światła skierowane na postaci. Aktor rozpoczynajacy swoją kwestię jest oświetlony trochę mocniej.

\section{ANNA}

(trzymajac CHIMKA za rękę)

Mam nadzieję, że będę potrafiła uczynić go szczęśliwym.

\section{TADEUSZ}

Mam nadzieję, że wyswobodzę się z nałogu.

\section{ZACHARY}

(trzymajac rękę na ciężarnym brzuchu ANNY)

Mam nadzieję, że Janek będzie zdrowym chłopcem.

\section{STARUSZKA}

Mam nadzieję, że mój syn na nowo zrozumie, co jest w życiu najważniejsze. 


\section{HIOB}

Mam nadzieję, że moje cierpienie nauczy mnie pokory.

Wszystkie światła gasną, aktorzy staja w półkolu. Na ekranie wyświetla się napis oraz zostaje odtworzony fragment homilii Jana Pawła II - „Dla chrześcijanina sytuacja nigdy nie jest beznadziejna. Chrześcijanin jest człowiekiem nadziei” (Homilia, Gdańsk-Westerplatte, 12.06.1987).

\section{KONIEC}

Paulina Józefowska, „Spes confisa Deo”, [w:] Nadzieja. Nagrodzone i wyróżnione prace konkursowe, red. Katarzyna Dybeł, Zofia Zarębianka, Kraków 2015, s. $42-49$ (Dni Jana Pawła II). http://dx.doi.org/10.15633/9788374384650.05 